\title{
Papel e imagen social de las mujeres libres en los poemas homéricos desde la perspectiva de su alteridad
}

\author{
Social role and picture of free women in Homeric poems from \\ the view of their alterity
}

\author{
BÁRBARA ÁLVAREZ RODRÍGUEZ*
}

Resumen: El tipo de identidad que encontramos en los protagonistas de los poemas homéricos no es individual, sino colectiva, y viene caracterizada por el hecho de ser aqueo, varón y noble, condición que se adquiere por nacimiento. Los miembros de este grupo tienen en exclusiva la capacidad de tomar parte activa en la sociedad, de modificarla y construirla, a través de su participación en un órgano político, la asamblea, y de su papel de liderazgo en la guerra. A partir de esa definición paradigmática de la identidad dominante se construye, por vía de la negación, la alteridad. Entre los muchos grupos de Otros con los que se relacionan los protagonistas de los poemas se encuentra el grupo de las mujeres. El objetivo de este artículo será analizar tanto el papel y la representación que se hace de ellas, como estudiar el tipo de relación que se da con entre la identidad masculina y la alteridad femenina.

Palabras clave: poemas homéricos, mujeres, alteridad, identidad dominante, asimetría.

\begin{abstract}
The main identity in Homeric poems is not individual but collective and is represented by being Achaean, male and noble, states acquired at birth. The members of this group have the exclusive capacity of taking an active part in society, of changing and building it, by taking part in a political institution, the assembly, and their leadership role in war. From this archetypal definition of the dominating identity we can construe - negatively - alterity. Women are included in one of this Other's group. The aim of this paper will be to analyze which role had women, how they were symbolized in the poems and which kind of relationship occurs between the bearers of identity and the alterity represented by women.
\end{abstract}

Keywords: Homeric poems, women, alterity, dominating identity, asymmetry.

\section{Introducción: consideraciones preliminares}

El objetivo del presente artículo es, en primer lugar, analizar la imagen social y el papel que ocupan las mujeres libres en las comunidades de los poemas homéricos ${ }^{1} \mathrm{y}$, en segundo, estudiar qué tipo de relación se establece entre éstas y los varones protagonistas de los mismos.

Fecha de recepción: 12/05/2014. Fecha de aceptación: 16/06/2016.

* Investigadora postdoctoral "Clarín-COFUND” en el Departamento de Clásicas de la Universidad de Stanford, balvarod@stanford.edu. Este trabajo ha sido posible gracias al programa de becas predoctorales "Severo Ochoa" y al de becas postdoctorales "CLARIN-COFUND" del Principado de Asturias.

1 Para una visión más amplia del papel de las mujeres en la Antigüedad griega v., por ejemplo, Cantarella E., Pandora's Daughters: the role and status of women in Greek and Roman antiquity, Baltimore and London, John Hopkins University Press, 1987; Blundell S., Women in Ancient Greece, Harvard University Press, 1995. 
$\mathrm{Al}$ analizar la Ilíada y la Odisea como fruto de una época, y recipientes de la memoria histórica de la misma ${ }^{2}$, veremos cómo ambos poemas ponen de manifiesto el establecimiento de jerarquías de dominación de unos grupos de humanos por encima de otros, mecánica que ha acompañado a todas las sociedades, al menos, Occidentales, hasta nuestros días. En el caso concreto que compete a este artículo, se observa cómo en ambos poemas se contrapone a la mujer a los valores guerreros, siendo vista como la imagen de la debilidad. Así, por ejemplo, cuando los jefes aqueos están enfadados por la cobardía de sus huestes los llaman “aqueas que no aqueos" (cf. Il. II 234-235 e Il. VII 96).

El marco teórico en el que se inscribe este trabajo es, principalmente, el esquema de la alteridad ${ }^{3}$ que el doctor Gabriel Bello Reguera ha desarrollado en su libro Emigración y ética. Humanizar y deshumanizar. A pesar de que las diferentes categorías del esquema son teóricas, lo realmente valioso e importante de éste es que puede aplicarse en la práctica a las distintas relaciones que se dan o han dado entre sujetos reales (o, como en esta ocasión, entre personajes literarios) en el marco de lo social o de lo temporal. Su base es ética y política, al igual que las consecuencias que se siguen de las relaciones que se dan entre los sujetos que han sido etiquetados como «Otros» y los que tenían el poder de etiquetarlos, el Yo o Nosotros.

2 Havelock es un ferviente defensor de algo con lo que estoy completamente de acuerdo: el uso pedagógico de los poemas homéricos en la Antigüedad griega. Los poemas homéricos servían para enseñar los nómoi y los éthea a los griegos, es decir, las leyes consuetudinarias y las pautas de comportamiento personal. A este uso de los poemas Havelock lo denominó “enciclopedia tribal”. V. Havelock, E. A., Prefacio a Platón, Madrid, Antonio Machado Libros, 2002, pp. 71-93.

3 El esquema de las relaciones con la alteridad se podría resumir de la siguiente manera: la primera delimitación que debemos tener en cuenta es la que viene determinada por si la alteridad se inscribe dentro de criterios humanos o no. En función de esto, la alteridad puede ser vista como neutra o impersonal, si los entes que se engloban bajo ella no son humanos o como personalizada o generizada, si los Otros que aquí se inscriben son humanos (como es el caso del grupo de las mujeres). Esta última se encuentra inmersa en el tiempo y en el espacio, lo que originará, a su vez, dos subtipos de relación: el primer subtipo se da en virtud de categorías temporales. Según los Otros pertenezcan al pasado, al futuro o al presente serán nuestros antepasados, nuestros sucesores o nuestros contemporáneos. En este último caso, la clasificación se vuelve a dividir atendiendo a si los Otros contemporáneos pertenecen a nuestra cultura o no lo hacen. El segundo subtipo se inscribe dentro de categorías socio-espaciales y siempre se darán dentro del presente humano. A su vez, este segundo subtipo se divide en cuatro, que obedecerán a los cuatro modos posibles de relación con el Otro contemporáneo (que es donde se inscribiría el grupo de las mujeres en los poemas): el primero de ellos es la relación simétrica positiva y es la que se da entre dos Yos o dos Nosotros que se reconocen como iguales y no intentan imponerse mutuamente. El segundo modo de relación es el que obedece a criterios simétricos negativos y es el que se origina cuando dos Nosotros pugnan por imponer su propia identidad y dominarse mutuamente. El tercer tipo es la relación asimetría negativa que se da cuando un Nosotros toma su propia identidad como norma y pretende imponerla a un ellos como si fuera la identidad universal. En este tipo de relación suelen darse dos clases de tratamiento al Otro: o se lo excluye de la identidad dominante, en dicho caso, deshumanizándolo políticamente, o se lo intenta asimilar a esa misma identidad, negándole su identidad propia. En último lugar, nos encontramos con la relación asimétrica positiva que es la que se da entre un Yo y un Otro vulnerable del que el Yo es responsable. Averiguar en cuál de estos cuatro modos se inscribe la relación con las mujeres en los poemas es, como se ha dicho, parte del objetivo de este artículo. Para más información, v. Bello, G., Emigración y ética. Humanizar y deshumanizar, Madrid, Plaza y Valdés, 2011, pp. 83-116. 


\section{Representación general de las mujeres libres en los poemas}

En Homero la mujer noble llega a definirse únicamente por los hombres con los que le ha tocado compartir su vida, es decir, a través de la identidad del varón. Esto se ve muy bien en el canto XI de la Odisea, cuando el propio héroe describe sus encuentros en el Hades con catorce «esposas e hijas de héroes notables» (Od. XI 227). En este episodio, las mujeres son definidas por su condición de «hija de», «esposa de», o «madre de» un varón ilustre. Ellas mismas se presentan a Odiseo relatando su estirpe (Od. XI 233-234), la cual vendrá definida por la figura del hombre de la casa (ya sea el ô̂kos paterno o el del marido) ${ }^{4}$. Pero también en el caso de las mujeres vivas es a su padre, primero, y a su marido, después, a los que el poeta recurre para definirlas como seres sociales. En la Ilíada, por ejemplo, a las troyanas no se las llama de este modo sino "esposas e hijas de troyanos" (cf. Il. VI 238) o, únicamente, "esposas de troyanos" (cf. Il. VII 80). De esta manera, la mujer no es propiamente, sino que es en virtud de ser hija, ser madre o ser esposa. El ser social a la mujer noble le viene dado desde fuera, pasivamente, ella lo recibe, no lo posee por sí misma. Sin embargo, sí tiene la capacidad activa de causar la deshonra o vergüenza de su familia, como vemos, por ejemplo, en los casos de Erifile y Epicasta (Od. XI 327 y Od. XI 272-273).

Por otra parte, los códigos de conducta que preconizan las mujeres homéricas responden a valores masculinos, aunque sean ellas mismas las encargadas de que se cumplan. Así, escuchamos a Nausícaa decir que ella sería la primera en indignarse con otra mujer que «hiciera cosas semejantes/ y que contra la voluntad de su padre y de su madre/ se uniera con hombres antes de celebrar público matrimonio», Od. VI 286-288). O a Helena negándose a compartir el lecho con Paris por temor a que, después, todas las troyanas la censuren (Il. III 410-412). También Penélope afirma temer los comentarios de irritación de las otras mujeres de su pueblo si llega a dejar a su suegro, Laertes, sin sudario para el momento de su muerte (Od. II 101-103; Od. XIX 144-146 y Od. XXIV 138-136). Y en Od. XVI 73-75 Telémaco dice que su madre no sabe si volver a casarse o esperar a Odiseo "sintiendo vergüenza por el lecho de su esposo y las habladurías del pueblo", idea que se repite en Od. XIX 526-527.

Es interesante señalar que el término utilizado para expresar este sentimiento es aíó́s, vocablo que significa tanto "vergüenza" como "respeto", en referencia, en cualquier caso, a un sentimiento orientado hacia el exterior, hacia el «Otro». Fue Dodds ${ }^{5}$ el primero en poner de manifiesto que el mundo representado en los poemas homéricos se puede entender como una cultura de la vergüenza, frente a una cultura posterior de la culpa. En los ejemplos antes mencionados, se ve cómo la vergüenza hacia el «Otro» contemporáneo aparece actuando como regulador de la conducta y como sentimiento que, al mismo tiempo, apela a la responsabilidad. Permiten ver cómo el aidós tiene una doble vertiente: se trata de un sentimiento de vergüenza, respeto y responsabilidad hacia el otro, que influye en gran medida en la conducta de las personas, moviéndolas a actuar en función de la representación que cada uno se hace de la respuesta que su comportamiento va a provocar en los «Otros» de su propio grupo. En el mundo que aparece representado en los poemas homéricos es tal la

4 V., por ejemplo, Od. XI 236-237; Od. XI 317-320; Od. XI 260-261; Od. XI 266; Od. XI 269-270; Od. XI 281285; Od. XI 298-300; Od. XI 322.

5 Dodds, E. R., Los griegos y lo irracional, Madrid, Alianza, 2008, pp. 15-70. 
importancia que tiene la mirada o, el efecto de la mirada, del «Otro» en el propio rostro que el reflejo llega incluso a volverse insoportable. $\mathrm{El}$ «Otro» funciona a manera de un espejo en el que cada uno se reconoce, lo mismo que la mirada de reproche del «Otro» es causante de la propia vergüenza. Tanto el reconocimiento como la vergüenza son categorías externas, van del individuo hacia el exterior. Ya Sartre había percibido esta relación entre vergüenza y reconocimiento y, así, dice: "Tengo vergüenza de mí tal como aparezco al otro [...] La vergüenza es, por naturaleza, reconocimiento. Reconozco que soy como el otro me ve"6. El aidós surge cuando la falta es contemplada por otros, y se perpetúa cuando los testigos la difunden al resto del grupo, que, a su vez, puede hacer que permanezca en la memoria futura y esto puede llegar a ser insoportable. Así, por ejemplo, Helena desea su propia muerte por la vergüenza que le produce su comportamiento como adúltera: en el canto III de la Ilíada, Príamo la llama para interrogarla sobre la identidad de algunos combatientes aqueos y ella se acerca a él avergonzada ( $\alpha i \delta o i o ́ s)$ y comienza su parlamento diciendo que ojalá hubiera muerto cuando llegó a Troya en compañía de Paris (Il. III 172-175). Algo parecido ocurre unos cantos más adelante cuando ésta misma conversa con su nuevo cuñado Héctor y antes de comenzar su discurso se insulta, llamándose perra, y deseando haber desaparecido del mundo nada más nacer, con tal de que todo lo que estaba ocurriendo por su causa ${ }^{7}$ no hubiera sucedido (Il. VI 344-348).

A pesar de que no existe un sentimiento de cohesión grupal entre ellas (no tanto como amistad sino en un sentido más específico de conciencia de clase), la opinión colectiva de las mujeres influye en el comportamiento de las otras mujeres; ejerce las veces de regidor de conducta. Es así en estos ejemplos que acabamos de ver, pero su opinión parece que también se tiene en cuenta, a veces, entre los hombres: en la Ilíada, por dos veces Héctor habla de la vergüenza que sentiría ( $\alpha$ i̇́co $\mu \alpha \iota)$, si le viesen abandonar su posición en la batalla los troyanos y las troyanas (cf. Il. VI 441-443 e Il. XXII 104-106). Resulta pertinente, a estos efectos, mencionar que Benveniste 1983 (=1969), p. 219 sostiene que en Homero el vocabulario relacionado con los términos morales aún no posee un sentido individual, sino que está impregnado de valores sociales. Así, el aỉós que siente Héctor ante las mujeres define el sentimiento de responsabilidad para con el otro, del superior ante el inferior. Héctor se siente responsable de los miembros de su comunidad que, efectivamente, dependen de una u otra manera de él, incluyendo a las mujeres, justamente por su estatuto de inferioridad y de dependencia ${ }^{8}$; pero el simple hecho de tenerlas en cuenta como miembros del propio grupo a los que se les debe el honor, la defensa y el no abandono, ya es algo sumamente destacable de la actitud del héroe.

\section{Papel y función social de las mujeres libres en su condición de «hijas»}

El papel de la hija en la sociedad viene marcado por la necesidad de convertirse, más temprano que tarde, en esposa y madre.

6 Sartre, El ser y la nada, Madrid, Aguilar, 1982 p. 340.

7 En relación a esto es interesante señalar que Príamo no considera a Helena la causante de la guerra de Troya sino que la exculpa diciendo que, a su juicio, los culpables son los dioses (Il. III 164-166).

8 Benveniste, E., Vocabulario de las Instituciones Indoeuropeas, Madrid, Taurus, 1983 p. 219 relacionaba estrechamente el aidós con un sentimiento de responsabilidad de los superiores hacia los inferiores. 
La figura que, por antonomasia, presenta Homero como la hija soltera, paradigma, al mismo tiempo, de doncella noble, es la de Nausícaa ${ }^{9}$, princesa feacia, hija de Alcínoo y de su mujer, Arete. Cuando una hija entra en edad casadera, la necesidad de que contraiga un matrimonio ventajoso se vuelve de esencial importancia en una familia. La urgencia por el casamiento la muestra el poeta en el canto VI de la Odisea; allí vemos cómo Atenea, tomando la figura de una amiga de la joven, la acusa de negligencia (Od. VI 25) por encontrarse en casa sin atender a los vestidos que ella y su cortejo deberán lucir el día de su boda; boda que, según la diosa, no está lejos. La hija soltera, cuando llega a determinada edad, ha de prepararse para afrontar su nuevo papel en la sociedad: convertirse en esposa (lo que, por otra parte, por regla general, la trasladará localmente de un ôkkos a otro). Por tanto, ha de estar presta a los preparativos de la boda: una mujer dejada y que no se preocupara por estos asuntos provocaría la vergüenza del padre, ya que la gente hablaría mal de ella y, por extensión, de toda su familia. En cambio, una joven en edad casadera que se preocupa de sus asuntos (en este caso, de preparar y tener limpias sus ropas y las de su cortejo) provoca la admiración de las gentes de su pueblo: «Pues de estas cosas les viene noble fama a las personas,/ y se alegran el padre y la venerable madre», Od. VI 29-30.

A su vez, una mujer soltera debe guardar las apariencias: no podrá ser vista en compañía de un hombre ajeno al núcleo familiar antes de casarse, ya que este hecho acarrearía la deshonra para ella y para su familia. Así, Nausícaa aconseja a Odiseo que vaya a casa de su padre a pedirle hospitalidad, pero le advierte que, antes de llegar a la ciudad, se separe de ella y de sus sirvientas, con el fin de «evitar el amargo comentario», (Od. VI 273) que ello despertaría entre los feacios ${ }^{10}$. Efectivamente, si llega a ser vista en compañía de un varón desconocido, los feacios pensarían, como mínimo, que ya se había buscado un marido por su cuenta y, si fuera así, no sería tampoco correcto que se paseasen en público antes de oficializar el matrimonio (Od. VI 288).

Cuando una muchacha alcanza determinada edad, el padre parece verse en la urgente necesidad de buscarle un marido. Así, Alcínoo no duda en ofrecerle su hija al forastero Odiseo. En este caso concreto, sabemos, por la propuesta que le hace Alcínoo a Odiseo de dotar a su hija si éste la quiere por esposa (Od. VII 311-315), y por la propia categoría de rey de Esqueria que Alcínoo ostenta, que no era la necesidad pecuniaria la que lo urgía a tomar esa decisión. Parece, más bien, que tendría que ver con el miedo que tiene la propia Nausícaa a las habladurías de la gente, que vienen motivadas, obviamente, por el hecho de que se espera que las jóvenes lleguen vírgenes al matrimonio. Es decir, está en relación con lo que Dodds llamó (para referirse a la cultura homérica) una «cultura de la vergüenza» ${ }^{11}$. En la sociedad homérica lo que los miembros de la propia comunidad digan de uno tiene tanta importancia que es, en la mayoría de las ocasiones, lo que rige la conducta moral

9 Gil Fernández, L., llegó a llamar a Nausícaa «espejo de doncellas» en «El individuo y su marco social» en: Rodríguez Adrados, F., Fernández Galiano, M., Gil Fernández, L. y Sánchez Lasso De La Vega, J. (eds.), Introducción a Homero, Madrid, Labor, 1984, p. 365.

10 En la única otra ocasión en que Odiseo aparece a solas en compañía femenina (humana), en Od. VII 19-25 y 37-38, quien va con él es una niña pequeña (en realidad, Atenea disfrazada bajo la apariencia de una niña portadora de un cántaro). Antes de la edad núbil, las niñas, en principio, debían estar al margen de las habladurías de las gentes, aunque, a pesar de esto, Homero insiste en indicar que Odiseo no va a su lado, sino que la sigue unos pasos por detrás.

11 Dodds, E. R., op. cit., pp. 15-54. 
de la persona. Por otro lado, en este caso concreto, el que Alcínoo le ofrezca su hija a un extranjero, del que nada sabe, puede ser debido, como sostiene Vernant (1982 p. 63), a la inexistencia de alguien en la comunidad que estuviera a la altura de la muchacha casadera: «Concederla a un desconocido es una manera de no degradarla y de no perderla. Sin lazos familiares, lo único que puede hacer el yerno es integrarse en la familia del suegro y crear allí una descendencia que continuará su casa». En otras ocasiones, la elección del marido para la hija puede estar condicionada por motivos tales como la búsqueda de alianzas políticas ventajosas o de una mejora en el estatus de la descendencia (como podría ser el caso de las bodas de los hijos de Menelao en Od. IV 1-20), o, simplemente, el deseo de acrecentar las riquezas del padre, si éste recibe regalos a cambio de la hija.

La joven noble debe, por tanto, ser casada con alguien de su propio nivel social cuanto antes, a fin de garantizar su virginidad en el momento del matrimonio, evitando así las habladurías. Cabe añadir, además, que sólo la mujer casada adquiría el derecho de recibir honores de otros, tanto a nivel familiar (por parte de su marido e hijos) como social (por parte de las otras mujeres o de la comunidad en general). Así, se dice de la reina Arete: «a ésta Alcínoo la hizo su esposa, y la honró como no es honrada ninguna otra sobre la tierra/ de cuantas mujeres gobiernan su casa sometidas a sus esposos./ Así aquella ha sido honrada en su corazón, y lo es, / por sus hijos y el propio Alcínoo y el pueblo,/ quienes la miran como a una diosa», $\mathrm{Od}$. VII 66-71. Es decir, una mujer es honrada porque su marido le ha otorgado la honra (por su linaje y por sus riquezas, no hay que olvidar que la cultura que estamos analizando es una cultura aristocrática). Además, para que no nos llevemos a equívoco con respecto al gobierno de las mujeres en el ốkos, Homero se preocupa mucho de resaltar que, efectivamente, Arete es la más honrada de las mujeres que gobiernan su casa, pero ni en este espacio privado lo hará con plena autonomía y libertad, sino que lo hace bajo el sometimiento a su esposo (Od. VII 68).

\section{Papel y función social de las mujeres libres en su condición de «esposa»}

\subsection{El matrimonio. Aproximación etimológica a los conceptos relacionados con el matri- monio en Homero}

Ahora bien, donde mejor puede apreciarse la relación que se da en el mundo homérico entre la identidad dominante (patriarcal) y la alteridad que supone la mujer, es, sin duda, allí donde se habla del matrimonio.

¿Existe algún concepto en Homero que se aproxime a lo que hoy entendemos por «matrimonio»? Aristóteles, en su Política, decía que en su lengua, el griego, «la unión del hombre y la mujer carece de nombre» (Arist., Polit., I, 3, 1253b, trad. de Julián Marías y María Araujo, Instituto de Estudios Políticos, Madrid 1970), pero el filósofo se estaba refiriendo al matrimonio en abstracto, al hecho de que un hombre y una mujer mantengan una unión exclusiva y socialmente reconocida, de la que nazcan hijos legítimos. Porque para la boda, es decir, para la fiesta, el banquete con que se celebraba el acto del matrimonio, y que servía para

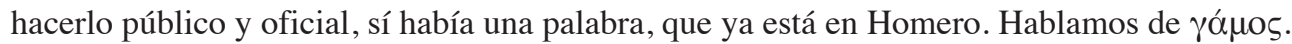

En los poemas, otros verbos que hacen referencia al acto de casarse, como ójví $\omega$ y

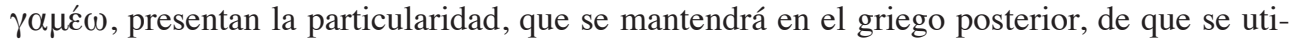

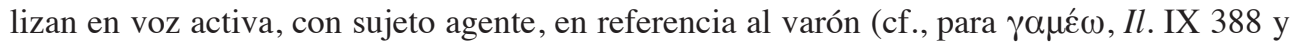


391; Il. XIV 122, Od. II 207, Od. IV 208, Od. XV 522, etc., y para óлví́ Il. XIII 379, Il. XIV 268, Il. XVI 178, Od. II 336, Od. VI 63, Od. XV 21, Od. XVI 386, etc.), pero en voz

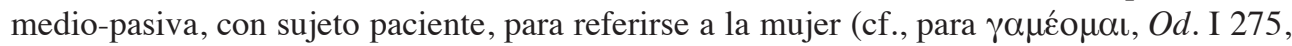

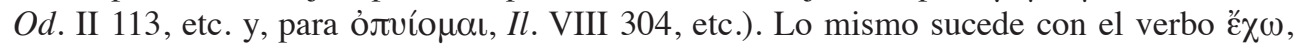
'tener', que en voz activa se emplea, bien con objeto, bien en uso absoluto, con el sentido de «tener por esposa» (cf., por ejemplo, Il. III 123, 336, Il. XI 740, Il. XIII 173, 697, Od. VII $313, O d$. XI 70 , etc.) y en voz medio-pasiva, con el de «ser tenida por esposa», «ser la esposa de» (Il. VI 398, único ejemplo en los poemas). Es decir, en el matrimonio el varón se concibe como un agente que realiza la acción de modo consciente y voluntario, mientras que la mujer se ve como un objeto paciente, sobre el que recae la acción.

\subsection{Los distintos tipos de matrimonio}

En el mundo homérico aparecen diversos tipos de matrimonio ${ }^{12}$, que se encuentran entremezclados, impidiendo así hacer afirmaciones categóricas sobre que exista un determinado tipo de contrato matrimonial predominante.

\section{a) El matrimonio con hédna}

Es el tipo de matrimonio más frecuentemente testimoniado en los poemas homéricos. También se lo ha denominado «patrilocal»o «virilocal»: el futuro marido da al padre de la novia una serie de regalos ( $\check{\delta} \delta \alpha)$ y la novia pasa a formar parte del oîkos del novio. La herencia permanece así, al igual que el traspaso del poder, en el hogar del padre del marido.

Que el matrimonio con hédna era el más normal lo atestiguan los múltiples episodios en los que se habla de él en los poemas ${ }^{13}$. La entrega de los hédna al padre de la novia se convertía, en la mayoría de los casos testimoniados, en condición indispensable para que se produjera el matrimonio, y para que la mujer pudiera abandonar el ô̂kos paterno y pasara a formar parte del ôkkos del marido. La magnitud de los hédna ejercía un papel primordial en la elección del novio, como lo atestigua el comentario de Penélope ${ }^{14}$ en Od. XIX 528-529, cuándo se plantea si continuar esperando el regreso de su esposo o si «seguir al que sea el mejor de los aqueos/ y me pretenda en el palacio, tras entregarme innumerables regalos de esponsales».

12 Para más información sobre los distintos tipos de matrimonio que aparecen en los poemas, v. García Sánchez, M., op. cit., 1999, pp. 51-74, Fraga Iribarne, A., De Criseida a Penélope. Un largo camino hacia el patriarcado clásico, Madrid, Horas y Horas, 1998, pp. 33-35 y Leduc, C., «¿Cómo darla en matrimonio? La novia en Grecia, siglos IX-IV a. C.» en: Historia de las mujeres en Occidente, Tomo I, Buenos Aires, Taurus, 1991, pp. 252-270.

13 V. Od. XI 117; Od. XI 282; Il. XXII 466-472; Il. XVI 178-180; Il. XVI 190-191.

14 Respecto al caso del matrimonio de Penélope en la Odisea, es muy interesante la lectura que realiza Vernant, J. P., Mito y sociedad en la Grecia antigua, Madrid, Siglo XXI, 1982 pp. 65-68. Éste afirma que, en el caso de Penélope, la soberanía del reino de Ítaca, en ausencia de su marido y siendo su hijo, Telémaco, aún un niño, la transmitía ella. De ahí que quien se casara con ella pasara a ocupar el lugar de Odiseo. Cuando Telémaco convoca el ágora, significa que ya se ha hecho hombre, por eso los pretendientes le proponen que envíe a su madre a casa de Ícaro y, en ese caso, ellos le entregarán los hédna al anciano. Ante la negativa de Telémaco de echar de su casa a su madre, los pretendientes planean matarlo, para acabar así con la soberanía que ya representaría Telémaco, e intentar conseguir de nuevo, a través de Penélope, la conquista del lugar que ocupaba Odiseo. 
Tradicionalmente, el matrimonio con hédna se ha identificado con un matrimonio por compra $^{15}$. Efectivamente, una primera lectura de los poemas puede llevarnos a la conclusión de que, en esos casos, la novia aparece como una mercancía con un determinado valor material. Sin embargo, Finley nos ha puesto sobre aviso de que estos hédna no podían entenderse como un simple precio, y la boda, como una compra de la mujer. Para afirmar esto, Finley anima a que nos fijemos en el tipo de sociedad mercantil que aparece en los poemas, prácticamente nula, si atendemos a las transacciones de compraventa. Hay muy pocos ejemplos en los poemas en los que aparezcan alusiones a comprar algo que no sean esclavos ${ }^{16}$. Finley (2000, p. 268), tacha este sistema mercantil de «rudimentario y severamente limitado», ya que pocas normas de ventas podían haber en una sociedad en la que las transacciones se hacían entre pueblos extranjeros, esto es, entre un grupo de hombres procedentes de una comunidad, y otros de una comunidad distinta que se encuentran esporádicamente. Más que de venta, debemos hablar aquí de intercambio de objetos, previamente aceptado mediante regateo por las dos partes, pero que, una vez efectuado, no comprometía a nada más, ya que, irremediablemente, después del intercambio una de las partes se iba a marchar (a su comunidad de origen $u$ otro puerto) a continuar con los intercambios ${ }^{17}$.

Es así, como una forma de intercambio, como señala Finley que hemos de ver el matrimonio por hédna. De la misma opinión es Vernant, quien sostiene, con Finley, que no se pueden entender los hédna como un mero precio a pagar por la novia, sino que son el símbolo material de una alianza entre dos familias. En el mundo aristocrático que presenta el poeta, el establecimiento de vínculos entre familias nobles de distintas comunidades era de vital importancia, con la finalidad última de ganarse un aliado político y económico, al que pedir (u otorgar) ayuda en situaciones críticas (que estaban a la orden del día). En los poemas aparecen dos formas de adquirir ese compromiso: mediante el matrimonio y mediante el ejercicio de la hospitalidad. Ante la carencia de un derecho escrito que legalizara ese contrato bidireccional que se establecía entre las familias, el vínculo se hacía visible mediante un intercambio de regalos ${ }^{18}$.

15 Como señala Vidal Naquet, P., «Economía y sociedad en la Grecia Antigua: La obra de Moses I. Finley» en: VVAA., Clases y luchas de clases en la Grecia Antigua, Madrid, Akal, 1979, p. 39, esta expresión pudo ser debida a la afirmación hecha por Aristóteles (y a la autoridad que se desprendía de éste) en Pol. II, 1268b 40, cuando dice: «pues las leyes antiguas son demasiado simples y bárbaras: así los griegos iban armados y se compraban las mujeres», trad. de Julián Marías y María Araujo, Instituto de Estudios Políticos, Madrid, 1970.

16 Entre las escasas excepciones, está el caso de Il. XVIII 289-291, donde Héctor habla de la necesidad que hubo de vender el oro y el bronce que había en la ciudad de Troya a Frigia y Meonia, para costear los gastos de la guerra; el de $I l$. VII 465-475, donde se mencionan unas naves, procedentes de Lemnos, que traían vino para el campamento aqueo, y donde la transacción se hacía mediante trueque (el vino se cambiaba por bronce, hierro, pieles, vacas o esclavos); y el de $O d$. XV 461-463, donde Eumeo se refiere a un grupo de fenicios que llegaron al palacio de su padre con mercancías que causaban admiración entre las mujeres de palacio, las cuales prometían un buen precio por las mismas (v. Od. XV 463).

17 Finley, M. I., op. cit., 2000, p. 269.

18 Cf., por ejemplo, las investigaciones del sociólogo Mauss, M., Ensayo sobre el don. Forma y función del intercambio en las sociedades arcaicas, Madrid, Katz, 2009, pp. 74-75, sobre las economías arcaicas. 
Es decir, las mujeres eran una parte del ejercicio del don y el contra-don ${ }^{19}$, símbolo material mediante el que se sellaba una alianza ${ }^{20}$. Y el matrimonio constituía sin duda una alianza política, como bien señala Finley (2000, p. 270). Es decir, nos encontramos ante una relación bidireccional entre dos familias. Una vez que ambas partes llegaban a un acuerdo, los hédna pueden ser considerados como el primer símbolo externo del pacto, el don. El segundo momento, el contra-don, era representado inequívocamente por la entrega de la mujer.

El propio motivo de la guerra de Troya ilustra de un modo especialmente elocuente la vertiente política del matrimonio entre nobles. Aunque en ninguno de los poemas homéricos se explica en detalle por qué los héroes aqueos se vieron obligados a participar en la expedición contra Troya acaudillada por Agamenón para traer de vuelta a casa a Helena, la esposa de su hermano Menelao ${ }^{21}$, los motivos subyacentes a este hecho sí parecen que hayan pasado a ser un topos literario tradicional griego ${ }^{22}$. Dado el gran número de pretendientes (prácticamente todos los nobles aqueos de la época) que se presentó ante Tindáreo, rey de Esparta, con la intención de casarse con su hija Helena ${ }^{23}$, éste temió que se produjera un descontento general entre los que resultasen rechazados, dando lugar a una guerra entre ellos. Por ello, haciendo caso a un consejo de Odiseo, Tindáreo hizo comprometerse a todos los jóvenes, mediante juramento, a acatar la decisión de Helena y acudir en ayuda del que fuese escogido, si se diera el caso de que la esposa le fuera disputada ${ }^{24}$.

\section{b) El matrimonio sin hédna}

Se trata de un tipo de matrimonio en el que el padre dota a la novia, y es el futuro esposo el que se integra en el ô̂kos de aquél, motivo por el cual a menudo se lo llama también «uxorilocal» 25 . En el caso de que la novia no tuviera hermanos varones, la herencia pasaría, a través de ella, al marido y a los hijos de ambos. De haber herederos varones del padre, el

19 El término para referirse al segundo momento del pacto, «el contra-don» o «contra-regalo», lo he tomado de Finley, M. I., El mundo de Odiseo, México, FCE, 1984, p. 76.

20 Benveniste, E., op. cit., 1983, p. 222 ve a la novia dada por el padre para que se integre en el ốkos del futuro marido como una prenda que sella el pacto de amistad (philotês) entre dos varones. Debemos aclarar, sin embargo, que el autor define la philotês como una amistad «de tipo perfectamente definido, que vincula y que comporta compromisos recíprocos, con juramentos y sacrificios», id., p. 221.

21 Quizás la mención más explícita al respecto se encuentra en un parlamento de Aquiles (Il. IX 336ss.) cuando, iracundo por el robo de su cautiva Briseida a manos de Agamenón, se pregunta si acaso los Atridas aman más a sus mujeres, puesto que la causante de que argivos y troyanos se encuentren ahí luchando no es otra que Helena. Otra alusión, tal vez menos directa, se encuentra en Il. I 152-160, donde, nuevamente, Aquiles le dice a Agamenón que él no ha acudido a luchar a Troya por causa de los troyanos, que jamás le causaron mal alguno, dada la lejanía entre Ftía y Troya, sino «para obtener honor para Menelao y para ti, ojos de perro,/ frente a los troyanos», Il. I 159-160. El poeta da por hecho que el auditorio al que dirige su poema conoce previamente los antecedentes de la historia.

22 Así lo encontramos repetidas veces en obras posteriores, como por ejemplo, en Eurípides Ifigenia en Áulide 57-71; Isócrates Helena 40-41 y Apolodoro Biblioteca III 10, 9. Un texto de épica arcaica que sí menciona de forma explícita los juramentos de los pretendientes es Hes. fr. 204 M.W.

23 Tindáreo era, según la tradición, el padre putativo de Helena, la cual era, en realidad, hija de Zeus y Leda, la esposa de Tindáreo.

24 Cf. Grimal, P., Diccionario de mitología griega y romana, Barcelona, Paidós, 2008, s.uи. «Helena», «Odiseo» $\mathrm{y}$ «Tindáreo».

25 V. García Sánchez, M., op. cit., 1999, p. 60. 
nuevo esposo adquiriría una posición subordinada al jefe de la familia. Al novio se le exime, a su vez, de la aportación de los hédna, aunque, en ocasiones, se le exige la realización de alguna hazaña previa en beneficio del padre de la novia, aunque no siempre es así.

El caso más paradigmático de este tipo de matrimonio, en el que la herencia acaba pasando al novio a través de su esposa, es el de Belerofonte ${ }^{26}$, a quien el rey de Licia (a quien, en un principio, le habían encargado que matase a Belerofonte), acabó por entregarle la mitad de su reino en vida, y la mano de su hija (Il. VI 192-195), después de que el héroe realizase una serie de hazañas asombrosas (Il. VI 180-189). Así, Belerofonte llegó a convertirse en rey de Licia a través de su mujer, es decir, por línea femenina.

En las otras ocasiones en que se menciona en los poemas este tipo de matrimonio, la presencia de hijos varones del padre de la novia hace que el marido de ésta quede excluido de la herencia, y sometido a la condición de mero subordinado de su suegro ${ }^{27}$. Por ejemplo, en Il. IX 141-156, Agamenón, que tiene un hijo varón, Orestes, le ofrece a Aquiles, entre otras muchas cosas, con tal de que vuelva a la lucha que escoja como esposa a cualquiera de sus tres hijas, ávó $\varepsilon \delta v o \varsigma$ («sin necesidad de pagar los hédna», Il. IX 146). En lugar de eso, sería el propio Agamenón el que dotaría a su hija con muchísimos regalos (Il. IX 138-149). Por otro lado, Agamenón no exige estrictamente que Aquiles pase a integrarse en su ô̂kos, sino que le da la posibilidad de que se lleve a la esposa elegida a casa de su padre, Peleo, en Ftía (Il. IX 145-146). No hay que olvidar que Aquiles es, a su vez, el único heredero de su padre. Con todo, Agamenón añade a la oferta de matrimonio entregarle a Aquiles siete ciudades cercanas a Pilos que están bajo su dominio; puesto que se trata de territorios secundarios, Aquiles, de aceptar la oferta, pasaría a ser un rey o príncipe menor, subordinado a la autoridad principal de Agamenón ${ }^{28}$.

\subsection{Papel y representación de la mujer casada en la sociedad}

Mientras que las actividades propias del hombre homérico (la asamblea y la guerra) se desarrollan fuera del espacio privado, las de la mujer están íntimamente vinculadas al ámbito

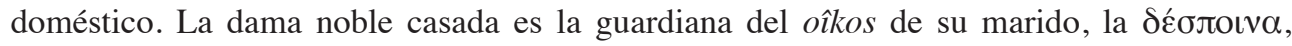
'señora' de sus esclavos, y quien debe ocuparse de que en el hogar todo funcione correctamente, y de que se cumplan las normas sociales generalmente aceptadas, así como la voluntad del esposo. Es curioso que el término masculino equivalente a $\delta \varepsilon ́ \sigma \pi o \iota v \alpha$, es decir,

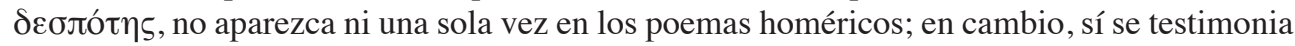
con mucha frecuencia otra palabra de la misma familia, đóoı, inicialmente 'dueño', que ha pasado a significar básicamente 'esposo'.

26 La historia de Belerofonte se sitúa en un momento pasado con respecto al tiempo del relato de la Ilíada, y es narrada por su nieto, Glauco. En este sentido, estoy de acuerdo con Fraga Iribarne, A., op. cit., 1998, pp. 35-37 cuando asocia este tipo de matrimonio a los estratos más antiguos que aparecen en los poemas, esto es, los mitos o los recuerdos de las generaciones de los antepasados.

27 Del mismo modo que un hijo. En Il. IX 142ss. Agamenón dice que si Aquiles accede a ser su yerno sería considerado a la par que a su hijo.

28 V. Alden, M., «The Despised Migrant (Il. 9. 648 = 16.59)» en: Montanari, F. y Rengakos, C. T. (eds.), Homeric Contexts. Neoanalysis and the interpretation of oral poetry, Berlín / Boston, De Gruyter, 2012, p. 125. 
Hay algunos episodios en los poemas que, en una primera lectura, podrían llevar a engaño respecto al papel de la mujer en el hogar, haciendo pensar que está por encima de su marido. Así, por ejemplo, en la Odisea, cuando Nausícaa le dice a Odiseo que vaya al palacio a implorar ayuda, le aconseja que pase de largo a su padre y que, en cambio, eche los brazos suplicante a los pies de su madre, Arete $\left(O d\right.$. VI 310-315) ${ }^{29}$. Sin embargo, como indica J. B. Hainsworth ${ }^{30}$, parece que esto hay que interpretarlo como un signo de cortesía arcaica (si la señora está presente en la sala, hay que saludarla a ella primero), y no como un residuo de una antigua sociedad matriarcal. Si no, recordemos las palabras de Atenea sobre Arete, la más honrada «de cuantas mujeres, al menos ahora, gobiernan su casa sometidas a sus esposos», Od. VII 68). El esposo es, en última instancia, el dueño real de todo, y el que dicta la ley sobre cómo habrá de gobernar una mujer su casa.

Por otro lado, la mujer noble no está exenta de labores domésticas, aparte de la dirección de los esclavos, siendo su ocupación más típica la labor del telar, ya que las mujeres debían elaborar en casa las telas para la ropa de la familia (Od. VI 52-55; Od. VI 305-309; Od. VII 108-110). En la Ilíada Héctor le recuerda a su esposa cuáles son las tareas que le corresponden: «yendo a casa, ocúpate de tus propias labores,/ el telar y la rueca, y ordena a las criadas/ que atiendan a su tarea; la guerra, en cambio, ha de preocupar a los varones», Il. VI 490-492.

Debido a que su vida transcurre fundamentalmente en el ámbito doméstico, las mujeres libres aparecen en los poemas, normalmente, aisladas entre ellas: mientras que los varones dialogan y se relacionan continuamente entre sí, las mujeres apenas tienen contacto con otras iguales, fuera del ámbito familiar ${ }^{31}$, aunque al menos mientras son solteras sí se dice que tienen amigas ${ }^{32}$. Por otro lado, tampoco tienen una interacción libre con los varones, fuera de su actividad como anfitrionas de los huéspedes que son acogidos por sus maridos ${ }^{33}$. En este sentido, la situación de Penélope en la Odisea frente a los pretendientes que la fuerzan a acogerlos a diario en su palacio, en ausencia de un dueño de la casa, resulta especialmente violenta para ella. Así, cuando debe enfrentarse a los pretendientes, se hace acompañar por dos esclavas, y se vela la cara (Od. I 328-335). Así mismo, en un canto posterior dice: «...

29 Unos versos más adelante, en $O d$. VII 146ss., vemos cómo Odiseo cuando llega a palacio sigue el consejo de la princesa Nausícaa y se dirige, en primer lugar, a la reina Arete.

30 Heubeck, A., West, S. y Hainsworth, J. B., A Commentary on Homer's Odyssey, vol. I (cantos I-VIII), Oxford, Clarendon Press, 1988, p. 325 (comentario a VII 66 ss.).

31 V., p. ej., el episodio de las matronas troyanas yendo juntas al templo de Atenea, para suplicarle a la diosa que ayude al ejército troyano (Il. VI 287-305). Esta es una de las pocas ocasiones en las que el poeta habla de una reunión de mujeres libres, y hay que decir que no lo hacen por voluntad propia, sino que están obedeciendo las órdenes de Héctor (Il. VI 268-279).

32 Así se muestra, p. ej., en Od. VI 20-24 e Il. III 175.

33 Es el caso, p. ej., de Helena cuando su marido recibe como huéspedes a Telémaco y Pisístrato; los hombres se encuentran hablando, Helena baja de su estancia y conversa con ellos. Debe notarse, sin embargo, que Helena se dirige primeramente a su esposo (Od. IV 137-140) y los huéspedes en ningún momento le hablan directamente a ella, sino que lo hacen a través de Menelao (Od. IV 235-294). Unos cantos más adelante, también se presenta a Helena regalándole a Telémaco, como parte de los dones de hospitalidad, un peplo tejido por ella misma (Od. XV 124-126). Igualmente, en el canto III de la Ilíada, encontramos a Helena conversando con un varón, Príamo, pero, en esta ocasión, debe considerarse al troyano como parte de la nueva familia de Helena. Así también lo hace explícito el rey cuando llama a Helena "hija querida" (Il. III 162). Del mismo modo, unos versos más adelante, encontramos a Helena conversando con Héctor, su cuñado, pero esta escena difiere de la anterior en que, en esta ocasión, el esposo de Helena (Paris) se encuentra también en la sala (Il. VI 344ss.). 
Pero ordénales de mi parte a Autónoe e Hipodamía [dos de sus esclavas]/ que vengan, para que me acompañen en el palacio./ Sola no iré allí, entre los hombres, pues siento vergüenza», Od. XVIII 182-184).

\section{Conclusiones}

La relación con la alteridad que representan las mujeres en el imaginario homérico viene enmarcada por el propio carácter de la sociedad que se representa en los poemas: una sociedad patriarcal y sumamente estratificada, en donde son los varones aristócratas los poseedores de la identidad dominante, y en donde la comunidad, cuyos principios son los regidores exclusivos de la conducta, está dirigida por esos mismos varones nobles. Las mujeres son marginadas; es decir, son excluidas participativamente de esa sociedad, cuyos valores son los dictados por los varones, y cuyas normas están obligadas a seguir. Simplemente están ahí, no son. La comunidad griega es una comunidad cerrada, articulada en torno a la familia (dominada y regida por el varón cabeza de familia), en donde las leyes, incipientes y consuetudinarias, son discutidas en el ágora, de la que estaban excluidas las mujeres, y cuya defensa estaba en manos también de varones, preparados como guerreros. Y, como todas las comunidades, lleva en su seno la marca de lo común. La mujer griega es lo diferente; y como lo otro se contrapone, constructivamente, a lo común, no le quedará otro remedio que ser marginada en esa comunidad patriarcal y aristocrática.

La excelencia y la inclusión en la comunidad en este tipo de sociedad vienen determinados por la capacidad de luchar en la guerra y por la participación en la asamblea. Sobre la exclusión de las mujeres de la asamblea, son muy significativas unas palabras que Telémaco dirige a su madre, y en las que explicita cuál es el lugar de las mujeres en el mundo homérico: el telar, la rueca y mantenerse en silencio. La palabra es cosa de hombres, se dice literalmente: «La palabra debe ser cosa de los varones/ todos, y especialmente mía. Pues mío es el poder en la casa», Od. I 358-359. Es importante que sean los hombres los que tienen el poder de hablar. Además, no se debe olvidar que la palabra tiene una función social y las mujeres están excluidas de esta función. Es la identidad dominante la que dicta, según su propia normativa, el papel que debe ocupar la alteridad (subordinada, en todo momento, a los dictados de esa identidad patriarcal). En el mencionado episodio, Penélope no sólo ve como algo natural que un hombre le recuerde cuál es su sitio, sino que se marcha admirada (Od. I 360) al ver que su hijo ya se está convirtiendo en adulto, en poseedor de esa identidad autoritaria. Es decir, Penélope, como todas las mujeres, considera legítimo que un varón le diga cuál es su condición, y su condición es la de ser muda, estar excluida del discurso, del poder de la palabra. En este sentido, podríamos decir que con las mujeres se establece una relación de violencia excluyente; como bien sostiene Bello «la violencia excluyente no se presenta como violencia en estado puro, arbitraria y brutal, sino como violencia legítima y necesaria» ${ }^{34}$, si bien es cierto que en los poemas no se dan casos de violencia explícita hacia las mujeres ${ }^{35}$.

34 Bello Reguera, G., El valor de los otros. Más allá de la violencia intercultural, Madrid, Biblioteca Nueva, 2006, p. 25.

35 A excepción del episodio en el que Zeus amenaza a Hera con azotarla en $I l$. XV 17. 
El valor de las mujeres libres (primero hijas y después, esposas) parece que reside en su potencialidad para ser madres. Ellas dan a luz a los varones, pero todo lo valorable en este mundo de los poemas será transmitido por el linaje paterno: el honor, la gloria y el renombre. Las mujeres sirven a la sociedad, pero en el sentido más utilitarista del término. Así, podemos afirmar que la relación que se establece entre la identidad dominante y las mujeres homéricas es, en función de la tipología que nos sirve como marco teórico, asimétrica negativa: el Nosotros formado por la identidad dominante (entiéndase varones nobles) impone su normatividad y sus leyes de conducta, de inclusión y exclusión a un Ellos (aquí, Ellas). A las mujeres la única opción que les quedará será la obediencia, si no quieren ser (en el caso de las mujeres libres) repudiadas y devueltas al ô̂kos paterno, en donde tendrán, de todas maneras, que someterse al padre.

Por otra parte, hemos visto cómo la exclusión de la mujer en tanto que sujeto actuante está ya implícita en el vocabulario que acompaña a la principal relación social entre varón y mujer: el matrimonio. El lenguaje es un constructo humano, que, a veces abiertamente, a veces de un modo sutil, refleja la realidad social.

En este sentido, no estamos de acuerdo, por demasiado positiva, con la visión de la mujer homérica que da Madrid $^{36}$. Si bien es cierto que, como sostiene la autora, en la Ilíada y Odisea no se observan apenas los rasgos misóginos que, por otra parte, acompañarán a casi toda la literatura griega posterior, no es menos cierto que la situación de la mujer es de una total dependencia del varón ${ }^{37}$, cuya única función es mantener la descendencia de los hombres. Al hablar de los matrimonios en los poemas, Madrid (1999, p. 43) dice que «las relaciones entre los esposos se fundan en el respeto mutuo y la concordia», a lo que yo añadiría que se basaban en el respeto de la mujer hacia el varón como norma ${ }^{38}$. A los varones poco les importaba llevar una concubina a casa y que los hijos de esta unión, a pesar del desacuerdo de la mujer legítima, fueran criados por ellas. El respeto se lo debían ellas a ellos, sino, ya sabemos el futuro que les esperaba.

Además, hemos visto cómo la mujer homérica no posee una identidad propia, sino que, de poseerla, lo hará en virtud de los varones que tenga como tutor (primero su padre, después, su marido y sus hijos): ella siempre es definida a través de ellos. Así mismo, hemos observado cómo las mujeres libres se muestran doblemente aisladas, entre iguales y con respecto al mundo masculino, cuyos valores son, sin embargo, los que preconizan, fruto de la educación basada en un régimen patriarcal que reciben. Con todo, la opinión expresada por la colectividad femenina hacia otra mujer se manifiesta como regidora de la conducta de ésta. También hemos analizado cómo esa misma opinión de las mujeres es, en ocasiones, tenida en cuenta como moldeadora de la conducta masculina (cf. Il. VI 441-443 e Il. XXII

36 Madrid, M., La misoginia en Grecia, Madrid, Cátedra, 1999, p. 42.

37 Es, justamente, esta condición de vulnerabilidad la que hace que, en algunos casos, tengamos muestra de sentimiento de responsabilidad hacia ellas, como vimos, concretamente, en el caso de Héctor en $I l$. VI 441-443 e $I l$. XXII 104-106.

38 Conviene, quizás, recordar aquí los consejos que la sombra de Agamenón, asesinado por su esposa Clitemnestra, le da a Odiseo en el Hades sobre cómo ha de tratar a su mujer: «Por eso, ahora jamás seas tampoco tú benévolo al menos con tu esposa / ni le des a conocer todo plan que bien pienses, / sino comunícale una parte, y

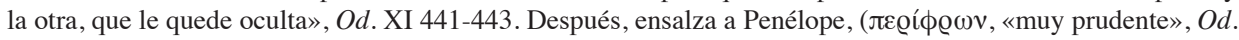
XI 445), pero luego vuelve a la carga diciéndole: «A escondidas, y no al descubierto, a tu amada tierra patria/ dirige tu nave, que ya no hay confianza alguna en las mujeres», Od. XI 455-456). 
104-106). Las mujeres son doblemente controladas: por los varones y por sus iguales. Las normas de conducta decididas para ellas por la autoridad patriarcal les vienen impuestas desde esa misma autoridad y desde las otras mujeres. Asumido totalmente cuál debe ser su papel en la sociedad, no les queda ningún sentimiento de cohesión grupal entre sí, en un sentido de conciencia de clase, anulado por la presión masculina externa, que las ha hecho interiorizar y aceptar como propios los valores y normas dominantes.

La mujer nunca es tratada como un individuo, sino que se ve como un género. En este sentido, es muy representativo un episodio de la Odisea en el que Agamenón habla sobre su asesinato a manos de su esposa, Clitemnestra, por cuya acción malvada se verá afectado todo el género femenino. Así, dice el rey de Argos: «Pero ella, experta en tamañas maldades,/ derramó la infamia sobre sí y sobre cuantas mujeres vendrán después,/ incluso la que sea de buen obrar» (Od. XI 432-434). Aquí vemos cómo la culpa de Clitemnestra parece que la heredarán las mujeres futuras: sus actos causarán infamia a las mujeres, contaminando a todo el género femenino. Lo que está diciendo Agamenón es que el mal comportamiento de su esposa influenciará en la futura consideración de las demás mujeres como, igualmente, deshonestas. Esto es, sin duda, una forma de anular la individualidad de las mujeres ya que, en Homero, esto jamás ocurre con los hombres: los actos inmorales de un individuo no se extenderán al resto con los que comparte género.

Nuevamente, en $O d$. XV 21, la mujer es generizada y esencializada, al asegurar Atenea que cuando una mujer se vuelve a casar, enseguida se preocupa de acrecentar la hacienda de quien la desposa y se olvida de su anterior marido e hijos. Visión, por otra parte, que a estas alturas no llega a sorprendernos mucho, ya que es muy acorde con el universo masculino y patriarcal que presenta el poeta en donde la sumisión de la mujer se hace evidente.

\section{Bibliografía}

Alden, M., (2012): «The despised migrant (Il. 9. 648 = 16. 59)», en Montanari, F. y Rengakos, C. T. (eds.), Homeric contexts. Neoanalysis and the interpretation of oral poetry, Berlín / Boston, pp. 115-131.

Altuna, B., (2010): Una historia moral del rostro, Valencia.

Austin, M. y Vidal-Naquet, P., (1986): Economía y sociedad en la antigua Grecia, Barcelona.

Autenrieth, G., (1991): Homeric Dictionary, Londres.

Bello Reguera, G., (2006): El valor de los otros. Más allá de la violencia intercultural, Madrid.

Bello Reguera, G., (2011): Emigración y ética. Humanizar y deshumanizar, Madrid.

Benveniste, E., (1983): Vocabulario de las Instituciones Indoeuropeas.

Blundell S., (1995): Women in Ancient Greece, Cambridge.

Bradford, E., (1989): En busca de Ulises, Barcelona.

Cantarella E., (1987): Pandora's Daughters: the role and status of women in Greek and Roman antiquity, Baltimore y Londres.

Chantraine, P., (1984): Dictionnaire étimologique de la langue grecque, vol. II, París.

Chantraine, P., (1990): Dictionnaire étimologique de la langue grecque, vol. I, París.

Dodds, E. R., (2008): Los griegos y lo irracional, Madrid. 
Edwards, M. W.; Kirk, G. S. (ed.) (1991): The Iliad: A Commentary, vol. V (cantos 17-20) Cambridge.

Fernández-Galiano, M., (1984): «El marco histórico de la epopeya», en Rodríguez Adrados, F., Fernández Galiano, M., Gil Fernández, L. y Sánchez Lasso De La Vega, J. (eds.), Introducción a Homero, Madrid.

Finley, M. I., (1984): El mundo de Odiseo, México.

Finley, M. I., (2000): Grecia antigua. Economía y sociedad.

Fraga Iribarne, A., (1998): De Criseida a Penélope. Un largo camino hacia el patriarcado clásico, Madrid.

García Sánchez, M., (1999): Las mujeres de Homero, Valencia.

Gil Fernández, L., (1984): «El individuo y su marco social», en Rodríguez Adrados, F., Fernández Galiano, M., Gil Fernández, L. y Sánchez Lasso De La Vega, J. (eds.), Introducción a Homero, pp. 357-487.

Gómez Espelosín, F. J., (2004): Introducción a la Grecia Antigua, Madrid.

Graziosi, B. y Haubold, J., (2008): «Men, women and society», en íd. Homer: the resonance of epic, Londres, pp. 95-119.

Grimal, P., (2008): Diccionario de mitología griega y romana, Barcelona.

Hainsworth, B.; Kirk, G. S. (ed.) (1993): The Iliad: A Commentary, vol. III (cantos 9-12), Cambridge.

Havelock, E. A., (2002): Prefacio a Platón, Madrid.

Heubeck, A. y Hoekstra, A., (1990): A commentary on Homer's Odyssey, vol. II (cantos IX-XVI), Oxford.

Heubeck, A., Russo, J. y Fernández-Galiano, M., (1992): A commentary on Homer's Odyssey, vol. III (cantos XVII-XXIV), Oxford.

Heubeck, A., West, S. y Hainsworth, J. B., (1988): A Commentary on Homer's Odyssey, vol. I (cantos I-VIII), Oxford.

Heubeck, A., West, S. y Hainsworth, J. B., (1988): A Commentary on Homer's Odyssey, vol. I (cantos I-VIII), Oxford.

Janko, R.; Kirk, G. S. (editor general), (1992): The Iliad: A Commentary, vol. IV (cantos XIII-XVI) Cambridge.

Kirk, G. S., (1990): The Iliad: A Commentary, vol. II (cantos 5-8), Cambridge.

Leduc, C., (1991): «¿Cómo darla en matrimonio? La novia en Grecia, siglos IX-IV a. C.», en Historia de las mujeres en Occidente, Tomo I, Buenos Aires, pp. 252-313.

López Eire, A., (2011): Ilíada de Homero, Madrid.

Madrid, M., (1999): La misoginia en Grecia, Madrid.

Mauss, M., (2009): Ensayo sobre el don. Forma y función del intercambio en las sociedades arcaicas, Madrid.

Redfield, J. M., (1992): La tragedia de Héctor. Naturaleza y cultura en la Ilíada, Barcelona.

Richardson, N.; Kirk, G. S. (ed.) (1993): The Iliad: A Commentary, vol. VI (cantos 21-24) Cambridge.

Saïd, S., (2011): «Women in the Odyssey», en íd. Homer and the Odyssey, Oxford: 258-314. Sánchez Ruipérez, M. y Tovar, A., (1983): Historia de Grecia, Barcelona.

Sartre, J. P., (1982): El ser y la nada, Madrid.

Vernant, J. P., (1982): Mito y sociedad en la Grecia antigua, Madrid. 
Vernant, J. P., (2008): Atravesar fronteras. Entre mito y política II, Buenos Aires.

Vidal-Naquet, P., (1979): «Economía y sociedad en la Grecia Antigua: La obra de Moses I.

Finley», en VVAA., Clases y luchas de clases en la Grecia Antigua, Madrid. 